\title{
Séance de la Chambre médicale
}

Points de l'ordre du jour déjà établis

- Accueil, communications

- Élections générales pour la législature 2020-2024

- Mesures de stabilisation budgétaire

- Rapports annuels 2019

- Comptes annuels 2019

- Octroi des décharges

- Réélection de l'organe de contrôle pour la période 2020-2022

- Modifications des Statuts, du Règlement d'exécution et du Code de déontologie

- Prestations médicales: respect des devoirs professionnels des médecins en entreprise

- Principes du nouveau financement de la collecte de données par les médecins

- TARDOC: révision du tarif ambulatoire

- MAS: information

- Informations du Comité central, du Secrétariat général, de l'ISFM et des divisions

- Divers

Tout nouveau point à l'ordre du jour doit être communiqué au Secrétariat central (direction[at]fmh.ch) d'ici au $1^{\text {er }}$ avril 2020. 